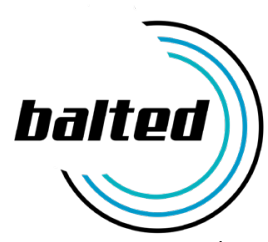

Balkanlarda Türk Dili ve Edebiyatı Araştırmaları

Studies on Turkish Language and Literature in the Balkans

Gezgin, F. (2022). Kosova-Gilanlı Gazeteci Burhan Sait'in Türk Dünyası ve Toplulukları Üzerine Yazıları. Balkanlarda Türk Dili ve Edebiyatı Araştırmaları, 4(1), 81-101. DOI: 10.47139/balted.987569

\title{
Kosova-Gilanlı Gazeteci Burhan Sait'in Türk Dünyası ve Toplulukları Üzerine Yazıları
}

\author{
Articles of Journalist Burhan Said from Kosovo-Gilan on the \\ Turkic World and Communities
}

Faruk GEZGiN*

\begin{abstract}
Öz
Tito'nun 1980' de ölümü ile federal yapının sarsıntı yaşaması ve 1990'larda ayrı bağımsız devletlerin oluşma süreci başlangıcına kadar, Yugoslavya'da birçok hakkı devlet garantisi altında olan Türkler için -aradaki Yücel teşkilatı davası, idam ve çeşitli mahkûmiyetlerle korkutulan Türklerin Türkiye'ye toplu göç olayı hariç- sosyalizmin devamına taraftar olan Burhan Sait, bunun yürümediğini ve her büyük halkın federal cumhuriyetini bağımsız devlet haline getirmeye başladığını görünce, esasen içinde var olan milliyetçi-Türkçü fikir çerçevesinde faaliyetler bulunur. Daha Tan gazetesinde muhabir ve yazar olarak çalışırken bölge Türklüğü ve Türk Dünyasıyla ilgilenmiş, yazılar yazmıştır. Üsküp'e yerleşip 1994-2002 arasında çıkardığı Vardar dergisi ve devamı olan Vardar gazetesinde Türk Dünyası ile daha çok ilgilenmiştir. Bu sırada bir ara Anadolu Ajansı Üsküp Temsilcisi olmasının verdiği imkânla, Türk Dünyası ile ilgili eline gelen bilgileri değerlendirip bazılarını haber, bazılarını da ayrı yazılar halinde yayınlamıştır. Atatürk'ten sonra Türk Dünyası'na yönelişin en bilinçli temsilcilerinden olan Milliyetçi Hareket Partisi Başkanı Alparslan Türkeş'e de hayran olan Burhan Sait, onun ölümüne genişçe veren bir haber-yazı da yayımlayarak bu hassasiyetini ortaya koymuştur. Bu çalışma için arşiv taraması yapılmıştır ve Kosovalı yazar ve gazeteci Burhan Sait'in Türk Dünyası ve meselelerine hasredilen yazılarına odaklanılmıştır. Örnek bir aydın üzerinden Balkan Türk entelijansiyasının Türk Dünyası'na yaklaşımı ve meseleleri ele alış biçimi örneklemeler üzerinden verilmiştir.
\end{abstract}

Anahtar Kelimeler: Türk Dünyası, Tan, Vardar, Burhan Sait, Alparslan Türkeş.

\begin{abstract}
Absract
Before the federal structure was shaken and separate independent states emerged in the 1990s, following Tito's death in 1980, the rights of the Turks were under the sta- te guarantee (excepting the case of the Yücel organization and the mass migration of Turks into Turkey due to fears of execution and various convictions), Burhan Sait was in favor of the continuation of socialism. However, he then realised that this did not work and that all big ethnic groups started turning their federal republics into independent
\end{abstract}

\footnotetext{
*Emekli Öğretim Görevlisi, Dokuz Eylül Üniversitesi, İzmir/TürkiYE, farukgezgin1950@windowslive.com, ORCID: 0000-0001-5800-1004
} 
states, he actually started to act within the framework of the nationalist-Turkist idea that existed in him. While working as a reporter and writer in the newspaper Tan, he was interested in the Turkishness of his region and the Turkish World and kept writing articles. He settled in Skopje and was even more interested in the Turkish World in the Vardar magazine and its sequel Vardar newspaper, which he published between 19942002. Meanwhile, owing to his role as the Anadolu Agency Skopje Representative for a while, he received a lot of information about the Turkish World and he started publishing some of these as news and some as separate articles. Burhan Sait was an admirer of the Chairman of the Nationalist Movement Party, Alparslan Türkeș, who had the most conscious interest in the Turkish World following Atatürk, and published a news article detailing his death. For this study, archive scanning was conducted and the articles of Kosovan writer and journalist Burhan Sait devoted to the Turkish World and its issues were focused on. The approach of the Balkan Turkish intelligentsia to the Turkish World and the way it handles the issues are given through examples through an example intellectual.

Keywords: Turkish World, Tan, Vardar, Burhan Sait, Alparslan Türkeş.

\section{Burhan Sait'in Kısaca Hayatı}

1965'te Kosova-Gilan'da doğan Burhan Sait, ailece vatandaşlığına geçtiği Türkiye'de 2004'te geçirdiği bir trafik kazasında ölmüştür. Kosova ve Makedonya'da 1989'a kadar önce gazete ve dergilerde çıkan şiirleri ve çıkardığı iki şiir kitabıyla ve yine aynı yıllarda, 1985-1993 arasında Tan gazetesi muhabirliği ve buradaki köşe yazılarıyla tanınmışırı. Onun Priştine'de çıkan Çevren dergisi ile Üsküp'te çıkan Birlik gazetesi ve Sesler dergisinde de şiirleri ve yazıları yayınlanır 1992-1994 arasında Üsküp'te Anadolu Ajansı temsilciliğinde bulunmuştur. 19942002 arasında ise Üsküp'te Vardar dergisi ve devamı olarak da Vardar gazetesini çıkaran Burhan Sait, gerek yazılarıyla ve gerekse fiilî olarak, Tito öldükten sonra Sosyalist Yugoslavya Federal Cumhuriyeti'nin son zamanlarında, Türklere daha önce sosyalist dönemde verilen Türkçe konuşma ve yazma ile Türkçe eğitim hakkının -1947-1948' deki Yücel teşkilatı davası sonucu verilen idam ve çeşitli hapis cezalarıyla korkutulan Türklerin Türkiye'ye büyük göçü olumsuzluğu hariçkısıtlanmasının, sosyalist rejimin dağılmasıyla kurulan Makedonya Cumhuriyeti ve Kosova Cumhuriyeti'nde de sürmesi karşısında devamlı Türkler için mücadele etmiştir. Bu iki yeni devlette, resmî makamların hukuk dışı ve inandırıcılıktan uzak gerekçeleri yüzünden Türkler, anayasalarda verilen haklarından halihazırda da çok az yararlanabilmektedir. Burhan Sait, Yugoslavya zamanında verilen haklardan Türkler büyük oranda yararlandığı için, rejim gereği sosyalist görünmek zorundaydı. Rejim dağılıp yeni kurulan iki devlette, Türklere verilen haklar kısıtlandığı için, ister istemez ruhunda esasen var olan milliyetçi-Türkçü ve Atatürkçü fikir dairesi içinde yer aldı. Onun çok sonraları Tito ve sosyalizm dosyasının açılması ve bilhassa Türklerin kolektif tarım siyaseti yüzünden ellerinden alınan 
toprak ve mülklerinin geri verilmesi gerektiğine dair yazıları vardır. Eşi ve iki kızı halen İstanbul'da yaşamaktadır.

\section{Burhan Sait'in Türk Dünyası Ve Toplulukları Üzerine Yazıları}

Atak, korkusuz, mücadeleci bir gazeteci olan Burhan Sait, bu yazılarında Osmanlı öncesinde Balkanlarda Türk varlığını, 1992-1994 arası Üsküp'te Anadolu Ajansı temsilciliğini yürütmenin verdiği imkânla Vardar dergisinin ilk sayılarında "Türk Dünyasından Kısa Kısa" şeklinde haberlerle Bulgaristan, Irak, Yunanistan, Azerbaycan, Türkmenistan, Kazakistan, Kırgızistan, Tataristan, Ahıska, İran, Kırım, Doğu Türkistan, Romanya, Özbekistan, Gagavuzya Türklerinin o sıradaki durumlarını; bölgesindeki ve dünyadaki Türklerin birliğinin gerekliliğini işler. Çeçenistan ve Abhazya'yı da Türk Dünyası içinde kabul eder. Bir yazısı, Türk Dünyasının saygı duyduğu bilge lider Alparslan Türkeş’in ölümü üzerinedir. Bir diğer yazısı da Makedonya ve Kosova'yı ikinci defa ziyaret eden Türkiye Cumhuriyeti Eski Kültür Bakanı Namık Kemal Zeybek'le yapılan mülakattır.

\subsection{Osmanlılardan Önce Balkanlarda Türk Varlığıyla İlgili Yazısı}

Burhan Sait, Tan gazetesinin "Tarihten Kesintiler" sütununda çıkan ve kaynaklara dayanan "Osmanlılardan Önce Bile Balkanlarda Türkler Yaşadı" yazsısında, o sırada Kosova'da varlığı inkâr edilmeye çalışılan Türklerin 4. ve 5. yüzyıllarda Attila Hunları, Avarlar, Bulgarlar, Oğuzlar (Gagavuzlar), Peçenekler, Kumanlar, Varderoitler olarak Balkanlara gelip yerleştiğini, siyasî üstünlüğü kaybedince bir kısmının katliama uğradığını, bir kısmının Ukrayna üzerinden Türkistan'a doğru çekildiğini ama geride kalanların Hristiyanlaşıp yerli halklar arasında asimile olduğunu, Slavca dilini konuşan halklara dönüştüğünü belirtir. Onun bu tespitine MÖ 7. ve 6. yüzyıllarda Türkistan ve Anadolu'daki hakimiyetini İran'a karşı kaybeden Sakaların-İskitlerin Balkanlardan Adriyatik'e kadar olan alanda varlıklarını devam ettirmelerini ve sonra eriyip yok olmalarını da eklemek gerekir. Balkanlardan Almanya'ya kadar birçok millette kültür unsurlarına rastlanması buna bağlıdır. Makedonya'daki ana dili Makedonca olan ve Makedonların onları aşağılamak için kullandığı “Torbeş”ler ile Kosova'da Şar Dağı'nda yoğun olarak yaşayan ve ana dilleri Slavca olan "Gora”|ılar bu eski Türklerden kalanlardır. Bunu Bulgaristan ve Yunanistan "Pomak"ları için de söylemek mümkündür. Hatta Doğu Makedonya'daki Hıristiyan Makedonların fizikî yapıları, Bulgar ve Oğuz Türk kavimlerini andırmaktadır. Burhan Sait, bu verilerden gurur duymuştur (Sait, 1990). 


\section{2. Türklerin Bir Olması, Bütünleşmesi ve Türk Birliği Üzerine Yazıları}

Her milliyetçi-Türkçü gibi Burhan Sait de Türk kavimlerinin-uluslarının, devletlerinin birliğini arzu etmiştir ama bunun duygu alanında kaldığının ve gerçekleşmesinin ekonomik ve siyasî güçlenmeyle ilgili olduğunun da farkındadır. Bir yazısının başlığı “Adriyatik'ten Çin Seddi'ne” dir. Sovyetler Birliği'nin yıkılmasıyla ortaya çıkan beş Türk cumhuriyeti ve diğer Türkler için Rusların ve Batılıların uydurduğu "Türkî" kelimesini maalesef o da kullanmıştır. Çarlık istilasına kadar "Türkistan" veya Türkçe "Türkeli" denilen coğrafyanın, 19. yüzyıldan itibaren "Orta Asya" denilip atlaslara geçirilmesi Rus emperyalizminin amacını yansıtmaktadır. Yeni bağımsız olan Türk devletlerinin kendilerine model olarak Türkiye'yi alması ve Türkiye Cumhuriyeti Başbakanı Süleyman Demirel'in “Adriyatik'ten Çin Seddi'ne dek bir Türk Dünyası mevcuttur" cümlesi Batı'yı korkutmaktadır. Hatta bir Davos toplantısında Süleyman Demirel'in Azerbaycan, Özbekistan ve Kazakistan cumhurbaşkanlarıyla görüşmesi ve beraber çektirdikleri fotoğrafın altına "yüzyıl geciken fotoğraf" ifadesinin yazılması, Batılılarca Türkiye'nin yayılmacı politika izlediği yorumlarına yol açmıştır. Burhan Sait, bunun tabiî bir ilişki olduğunu belirtir (Sait, 1992).

Burhan Sait, Makedonya'da 1991 nüfus sayımları sonuçlarının gerçeği yansıtmadığını, Makedonlar dışında diğer hakların bunu kabul etmediğini bilmektedir. O sırada Türklerin tek siyasî partisi olan Türk Demokratik Partisi de Türk nüfusunun 100.000 civarında değil, 150.000-200.000 arasında olduğunu, korkutma politikasıyla bunun sayım sonucuna yansımadığını ileri sürmüştür. Bu sayıya ana dili Makedonca olan 80.000-100.000 arasında nüfusları olduğu düşünülen Türk asıllıları da eklemek gerekir. Bu 250-300 binlik kitle, bugünkü durumda Makedonya Türklerini temsil eden üç parti ve Türkiye Cumhuriyeti yetkililerince iyi değerlendirilmemektedir. Seçim barajı yüzünden hiçbir Türk partisi seçimlere tek başına girmeye cesaret edememektedir. Üç partiyi bir platform altında toplamak teşebbüsleri de boşa çıkmaktadır. Arnavut siyasîlerin yok saydığı Türk partileri mecburen iki Makedon partisiyle iş birliği yapmakta ve listelere yerleştirme yüzünden uzun süredir meclise ancak iki milletvekili sokabilmektedir. Türkiye Cumhuriyeti de Makedonya Türk partilerini bir çatı altında toplamada pek istekli davranmamıştır. Türkler, sahipsizlik yüzünden ekonomiden eğitime kadar güç durumdadır. Doğu Makedonya'daki Türk çocukları bölgelerinde Türkçe lise eğitimi alamamaktadır. ADEKSAM derneği lise eğitimi için hem anadili Türkçe ve hem de ana dili Makedonca olan Türk çocuklarını Gostivar'daki çeşitli liselerde okutmaktadır. Ekonomik güçsüzlük ve iş bulamamak yüzünden birçok Türk genci Türkiye ve Avrupa ülkelerinde çalışmak zorunda kalmaktadır. Hatta bazı Türkler fırsatını bulunca Türkiye'ye göç etmektedir. Burhan Sait, çok partili hayat başlangıcında yaşanan heyecanın aksine, Türk partileri ve derneklerinin Türklerin sorunlarına 
çare olamadıklarını belirterek somut sonuçlar verecek çalışmalar yapılmasını tavsiye eder (Sait, 1993).

Burhan Sait'in dünyadaki Türklerin birliğiyle ilgili çok önemli bir yazısı da "AB Yoksa TB Vardır"dır. AET (Avrupa Ekonomik Topluluğu) veya sonraki adıyla AB'nin (Avrupa Birliği) 1960'lı yıllardan beri üyelik başvurusunda bulunan Türkiye'yi oyaladığını, her yeni görüşmede yeni şartlar olarak Kıbrıs, insan hakları ve hatta Kürt meselesini öne sürdüğünü görmüştür. Halbuki benzer sorunları olan İspanya ve daha sonra Bulgaristan birliğe alınmıştır. Üstelik Bulgaristan'ın ekonomik durumu Türkiye'nin çok gerisindeydi. Türkiye'yi veto eden Yunanistan, Batı Trakya'da Türklerin haklarını gasp etmektedir. Burhan Sait, Avrupa'nın hâlâ Haçlı zihniyetiyle hareket ettiğini, Bosna Hersek'te 200.000 Boşnak'ın Müslüman ve hatta Türk sayıldıkları için katledilmesine, Bulgaristan'daki Türklere yapılan baskılara da ses çıkarmadığını yazmıştır. O, Viyana bozgunundan sonra Avrupalıların Türkleri geldikleri Orta Asya'ya göndermek stratejisi olduğunun farkındadır. Bu konuda "1683 Viyana bozgunundan sonra rahat bir nefes alan ve Türkleri geldikleri Orta Asya'ya kovmayı vazgeçilmez bir ilke haline getiren haçlı zihniyeti Avrupa'nın sınırlarını Edirne'de görüyorsa da Balkanlarda kalan milyonlarca Türkleri de unutmuşa benzemiyor" diyor. Burhan Sait, AB'nin Türkiye'yi içine almayacağı inancındaydı. Bu gerçeğin görülerek Türkiye Cumhuriyeti’nin öncülüğünde Türk devletlerinin bir araya gelip Türk Birliği (TB) teşkilatının kurulması gerektiğine inanmıştır. Bu konuda “Azerbaycan'daki petrolden, Özbekistan'daki pamuk ve altından, Kazakistan'daki nükleer birikimden, Türkmenistan'daki doğal gazdan, Türkiye'deki ekonomi ve teknoloji potansiyelden doğacak bir TB, hiç kuşkusuz Avrupa Birliği'nin yeni alternatifi haline gelebilir, haçlı zihniyetin tüm dünyaya hâkim olma emellerine dur diyebilir" dese de, sonraki gelişmelere bakarak bu görüşün yavaş ilerlediği anlaşılmaktadır. Türkiye'nin başına bela olan teröre ABD ve $A B$ devletlerinin yardım etmesini de, bu teşebbüsün gerçekleşmemesi için yapıldığı şeklinde görmek gerekir (Sait, 1997, s. 3-5).

\section{3. Türk Dünyasından Haberler Yazıları}

KIBATEK Başkanı olarak Türk Dünyasıyla ilgilenen Feyyaz Sağlam, 1996'da Üsküp'te görüştüğü Burhan Sait'in Makedonya ve Kosova'da sayıları azalan Türklerin arkalarında 200 milyon Türk'ün yani Türk Dünyasının olduğuna inandığını belirtir (Mail, 2020; Sait, 1990).

1992-1994 arası Anadolu Ajansı Üsküp Temsilcisi olan Burhan Sait, ajanstan gelen Türk Dünyasıyla ilgili bilgileri, "Türk Dünyasından Kısa Kısa” başlığıyla Vardar dergisinin ilk sayılarında kısa haberler olarak vermiştir. Biz, bunların onun 
kaleminden çıktığını kabul etmek durumundayız. Bunlarda dünyanın değişik bölgelerindeki Türk devletleri, toplulukları ve diyarlarından haberler verilmiştir. Burada Burhan Sait'in yaşadığı Makedonya ve Kosova ile Türkiye'nin Vardar'da değerlendirilmediğini belirtmek durumundayız. Bu yazılar dergide "Vardar" adıyla çıkmıştır. Bazen Ankara'nın Türk Dünyasıyla ilgili olarak organize ettiği çalışmalar da duyurulur: Ortak değerler semineri, Aralık 1994'te Ankara'da yapılan Türk Dünyası Yazarlar Kurultayı'nda Türk Dünyasında yakınlaşmalar için çok önemli kararlar alındığı haberleri gibi (Vardar, 1994, s. 25-26). Ülkeler ve topluluklar halinde hazırlanan yazılar ve sunulan bilgiler:

KIRIM: Kırım Tatar Türklerinin vatana dönüşleri ve ekonomik durumlarının iyileştirilmeye çalışılması; çocuklarına Türkiye Türkçesi ile eğitim vermeye başlamaları; Ukrayna Meclisi'nin Moskova'nın Kırım'a müdahalesini kınayan kararının Rus Meclisi'ne gönderilmesi (Vardar, 1994, s. 26; Vardar, 1994, s. 25-26; Vardar, 1994, s. 25-26).

HOTON TÜRKLERi: Moğolistan'da nüfusu 5000 kadar olan ve kendilerini Türk olarak bilen toplulukla ilgili bilgi (Vardar, 1994, s. 26).

TÜRKMENISTAN: Türkiye firmalarının Türkmenistan'ı imar çalışmaları; Türkmenistan'da Latin alfabesinin okullarda kullanılmasının kararlaştırıması (Vardar, 1994, s. 26; Vardar, 1994, s. 25-26).

BATI TRAKYA TÜRKLERI: Batı Trakya Türklerinin, öğretmenlerinin Yunan hükümetinin bastırdığı ders kitaplarını okullarda kullanmadığı için mahkemeye verilmesi, para cezasına çarptırılmaları ve hatta meslekten atma uygulaması; Türk öğretmen ve aydınlara "Türk" kelimesini kullanmalarından ötürü ceza verilecek olması; Türklere uygulanan kısıtlamalar, İskeçe seçilmiş müftüsü Mehmet Emin Ağa'nın mahkûm edilmesi ve bunu Kopenhag Türk Kültür Derneği'nin protesto etmesi (Vardar, 1994, s. 26; Vardar, 1994, s. 25-26; Vardar, 1994, s. 25-26; Vardar, 1995, s. 27).

IRAK TÜRKLERi (TÜRKMENLER): Irak Milli Türkmen Partisi Başkanı Muzaffer Arslan'ın Irak'ın bütünlüğü içinde eşitliği savunması; Türkmenlere Arap ve Kürtlerden baskıların ve tutuklamaların olması; Saddam'ın askerden kaçanların kulaklarının kesilmesi konusunda bir kanun çıkarması; Türk ordusunun PKK için Kuzey Irak'a girmesi (Vardar, 1994, s. 26; Vardar, 1994, s. 25-26; Vardar, 1994, s. 25-26; Vardar, 1994, s. 25-26).

AZERBAYCAN TÜRKLERi: Bu başlık altında kuzey Azerbaycan'daki Azerbaycan Cumhuriyeti haberleri verilmiştir. TiKA'nın yatırımıyla TRT 1 yayınlarının Nahçıvan dahil Azerbaycan'da rahatça izlenmesi; Karabağ savaşı yüzünden oradan ve 
Ermeniler tarafından diğer işgal edilen Azerbaycan topraklarından Bakü’ye göç eden Türklerin perişan durumu; Türk Cumhuriyetleri Zirvesi'nin aradaki ihtilaflar yüzünden İstanbul'da yapılmasının kararlaştırılması; Seyfettin Altaylı'nın 2 ciltlik Azerbaycan Türkçesi Sözlüğü eserinin çıkması; Azerbaycan Cumhuriyeti'nin Ermenilerle savaşta Rusya'dan tarafsız olmasını istemesi ve Ermenilerin işgal ettiği yerlerden derhal çekilmesinin istenmesi; Türkiye'nin Karabağ için temasta bulunması; Azerbaycan'da bazı eski yöneticilerin mahkemelerce mahkûm edilmeleri ve bazılarının Moskova'ya kaçmaları; Nahçıvan Özerk Yönetiminin yardımlarından dolayı Türkiye'ye minnet duyması (Vardar, 1994, s. 25-26; Vardar, 1994, s. 26; Vardar, 1995, s. 27; Vardar, 1995, s. 27; Vardar, 1996, s. 25-26).

GAGAVUZ TÜRKLERi: Gagavuzların ayakta durması için Türkiye'nin desteğine muhtaç olması; Gagavuzistan'ın Sesi yazarı Petri Yarancı'nın II. Türk Dünyası Kurultayı için geldiği Türkiye'de, komünist rejim baskısına rağmen Türkçelerini koruduklarını, matbaaları olmadığı için Latin alfabesine geçemediklerini belirtmesi; Gagavuzya'daki 36 yerleşim yerinden 29'unun Gagavuzya Özerk Yönetiminde kalmayı kabul etmesi (Vardar, 1994, s. 25-26; Vardar, 1994, s. 25-26; Vardar, 1995, s. 26-27).

KAZAKiSTAN: Kazakistan'da "Yesevi Vatan" adıyla ayrı siyasî toprak oluşturulması, burada Türk Dünyası için yapılacak çalışmalar için Türkiye, Özbekistan ve Türkmenistan'dan yardım beklenmesi (Vardar, 1994, s. 25-26).

DOĞU TÜRKisTAN: Doğu Türkistan'da 9 toplama kampı olduğu, 80.000 siyasî tutuklunun bulunduğu, bölgede platin, altın, gümüş, kömür madenlerinin ve petrol yataklarının olduğu; Doğu Türkistan Uygur Milli Demokratik Halk Partisi Başkanı'nın TBMM'de yaptığı basın toplantısında, Doğu Türkistan'da 10 yıl içinde mecburi doğum kontrolü yüzünden 2.020 .000 bebeğin öldürüldüğünü ve evlenme yaşının 26'ya çıkarıldığını belirtmesi; Çin'in nükleer denemeleri bu bölgede Lop-Nor'da yapması ve Doğu Türkistan için gıda maddelerine kııılaştırıcı maddeler koyması (Vardar, 1994, s. 25-26; Vardar, 1994, s. 26; Vardar, 1994, s. 25-26; Vardar, 1995, s. 26-27).

İRAN TÜRKLERI: Urumiye, Tebriz, Zencan ve Marend Üniversitelerinde okuyan Azerî asıllı öğrencilerin, İran Anayasasının 15. maddesine dayanarak medyada, basında ve eğitimde Türkçenin kullanılmasına dair hazırladıkları deklarasyonu medya ve hükümete göndermesi (Vardar, 1994, s. 25-26; Vardar, 1995, s. 35).

TATARISTAN: Tataristan Yazarlar Birliği Başkanı Renat Muhammed'in kendilerine geldiklerini belirtmesi (Vardar, S. 4, Eylül 1994, s. 26).

BULGARISTAN TÜRKLERI: Hak ve Özgürlükler Hareketi'nin “Hak ve Özgür- 
lükler" adlı gazeteyi çıkarması ve asimilasyona karşı mücadele vermesi; nüfus sayımı sırasında Pomaklara kendilerini Türk yazdırmaları konusunda baskı yaptığı iddiasıyla Satovcha Belediye Başkanı Yusuf Cuco'ya hapis cezası verilmesi; eski Komünist Partisi'nin devamı olan Bulgaristan Sosyalist Partisi'nin 18 Aralık 1994 'teki seçim sonuçları üzerine iktidara gelince, azınlıklarla ilgili eski yasakları devam ettirme kararı ve Bulgaristan'da Bulgarlardan başka halklar olduğunu kabul etmemesi (Vardar, 1994, s. 26; Vardar, 1995, s. 27; Vardar, 1995, s. 27)

ROMANYA TÜRKLERI: Romanya'da 1994 yılında yapılan nüfus sayımı resmî sonuçlarına göre, Türk soyluların 29.533, Tatar Türklerinin 24.649 kişi oldukları ama Köstence'deki Romanya Müslüman Tatar Türkleri Demokratik Birliği'nin kayıtlarına göre, ülkedeki Türk ve Tatar nüfusunun aslında 500.000 kişi olduğu, bunun üçüncü azınlık grubunu oluşturduğu; Romanya Demokratik Türk Birliği'nin 20 Şubat 1996'dan itibaren Köstence'deki yeni adresinde faaliyetini sürdüreceği (Vardar, 1994, s. 25-26; Vardar, 1996, s. 25-26).

AHISKA TÜRKLERi: Ahıska Türklerinin Sovyetler Birliği'nin çok değişik yerlerinde iskân edildikleri yerlerden Gürcistan'daki ata yurduna dönmeleri için karar alınması, Gürcistan'ın buna yumuşak baktığı; Ağustos 1994'te Stalin döneminde yurtlarından sürülen çeşitli toplulukların Kabartay-Balkar Cumhuriyeti'nde toplantı yapması (Vardar, 1994, s. 25-26).

KIRGıZiSTAN: Kırgızistan'da dünyadan birçok turizm firmasının da katılımıyla ülkenin turizm potansiyelinin değerlendirildiği bir toplantının yapılması (Vardar, 1995, s. 27).

SATINLAR: Göktürklerden bugüne kalabilen Türk kavmi Satınların bugün Moğolistan'da Akköl'de 82 nüfusla varlıklarını devam ettirmeye çalıştıkları ve kendilerini Türk saydıkları, ren geyiği besledikleri (Vardar, 1994, s. 25-26).

ÇEÇENISTAN: Avrupa Parlamentosu'nun Rusya'nın Çeçenistan'da kirli bir savaş yürüttüğü, insan haklarını çiğnediği kararı (Vardar, 1995, s. 26-27).

ABHAZYA: Rusya'nın Çeçenistan sorunundan dolayı Abhazya sınııını kapatması sonucu Abhazların açlık sıkıntısı yaşaması (Vardar, 1995, s. 26-27).

\section{Türk Dünyası Üzerine Müstakil Yazıları}

3.1: Burhan Sait, iki yazısında 29 Ekim Cumhuriyet Bayramı'nın Türk Dünyası için öneminden, Türkiye'nin Türk Dünyası için tek umut kapısı, kaynağı olduğundan söz etmiştir. Ona göre, Mustafa Kemal'in İstiklal Savaşı'ndan başarı ile çık- 
ması ve yeni Türkiye'nin ilerlemesi sayesinde Balkanlarda Türklere eziyet biraz azalmıştır (Vardar, 1994, s. 3; Sait, 2000).

3.2: Türk Dünyası'nda ortak alfabenin kullanılmasını destekleyen Burhan Sait, Ankara'da 08.03 1993'te yapılan toplantıda 34 harfli Latin alfabesi üzerinde karar kılındığını yazmıştır. Yalnız bunun uygulamaya geçirilmesi için maddî kaynağa ihtiyaç vardır (Vardar, 1995, s. 25).

3.3. "Balkan Türkleri ve Demokrasi” yazısı: Burhan Sait, Bolşevik-totaliter rejimlerin tek bir ulusun iktidarını yarattığını, propagandanın aksine insanın ezildiğini ama demokrasiye geçen devletlerde Türklerin meclislere girmeye başladığını, mesela Bulgaristan'da 17 Türk milletvekilinin meclise girdiğini belirtir. Ama o sırada dağılmamış olan Yugoslavya'da Türk unsurunun Türk Demokratik Birlikleri ile kendini iyi temsil edeceğine dair umudu boşa çıkmış sayılabilir. Bu konuda " $Y u$ goslavya Parlamentosu'na da Türk unsurunun girebileceği inancındayken, Balkanlar'da yaşayan Türk unsurunun daha parlak bir geleceğe sahip olabileceği ve 45 yıllık bir bolşevik-totaliter rejimden kurtulacağı ümidi içindeyiz" diye yazmıştır. Nitekim hem Makedonya hem de Kosova'da Türk Demokratik Birliği partileşmiş, Makedonya'da bazen meclise milletvekili de sokamamıştır. Makedonya'da var olan Türk Demokratik Partisi içindeki ihtilaflar yüzünden Türk Güven Partisi, Türk Hareket Partisi ve Türk Milli Birlik Hareketi partileri doğmuştur. Güven Partisi sahneden çekilse de diğer Türk partileri faaliyetlerine devam etmektedir. Üç parti de seçim barajı yüzünden seçimlere tek başlarına değil; kendilerini öteden beri yok sayan Arnavut partileri yerine iki Makedon partisi listelerinden girmektedir. Son yıllardaki seçimlerde Türkler meclise ancak iki milletvekili sokabilmektedir. Halbuki Türkiye'nin girişimiyle üç Türk partisi bir çatı altına getirilse ve ana dili Makedonca olan Türklerin de tam desteği alınsa, seçim bölgelerinde baraj aşılabilir ve meclise 3-5 arasında milletvekili gönderme şansı olabilir (Sait, 1990).

3.4. Bulgaristan Türkleriyle İlgili Yazıları: Burhan Sait, bu konuda beş yazı yazmıştır. İlk yazısı, Belgrad TV 2 Kanalı'nda sunulan "Bulgar Türklerinin Göçü" yayını üzerine kaleme alınmıştır. Üsküp TV'si de göç eden Türklerin Kapıkule Gümrük Kapısı yakınında kurulan çadır kent ve İstanbul'a yerleşen Türklerle gerçekleştirdiği yayın da geniş ilgi uyandırır. Burhan Sait, 1975'te Bulgaristan'da Türkçe eğitimin yasaklandığını, 1985'ten itibaren de Türklerin adlarının Bulgarcalaştırılmaya başladığını, Türkiye'nin bu konudaki diyalog çağrılarına Bulgaristan'ın 
kulak tıkadığını ama 1989'da Türkiye ve dünya kamuoyunun baskısı karşısında bu uygulamadan vazgeçmek zorunda kaldığını, isteyen Türklerin Türkiye'ye göçüne izin verdiğini yazmıştır. Üsküp TV'si ad değiştirme zulmünün aileleri böldüğünü, zulmün başka etnik gruplara da uygulandığını duyurmuştur (Sait, 1989).

İkinci yazı, 1989 Kasım ayında yayınlanmıştır. 10 Kasım 1989'da Todor Jivkov görevinden istifa eder. Burhan Sait, bu istifada gerekli reformları yapmama kadar bir buçuk milyon Türk'e yapılan baskının da etkili olduğu kanaatindedir. Mladenov'la yeni bir dönemin başlayacağına inanmaktadır (Sait, 1989).

Üçüncü yazı, Bulgaristan'daki yeni gelişmeler üzerine yazılmıştır. Jivkov Komünist Partisi'nden atılır. Parti önünde 200.000 kişi miting yapar. Türkiye, gelişmeleri dikkatle izler, Türklere yapılan haksızlıklarla ilgili bir rapor hazırlanır. Komünist Partisi'nin ne yapacağı belirsizdir. "Önemle vurgulamamız gerekir ki, son zamanlarda artık Türkçe konuşanların cezalandırılmadığını, sünnet ve diğer uygulamalarda serbest bırakıldıklarını görüyoruz. Yakın bir gelecekte Türk isimlerinin yeniden kullanıma gireceklerine de mutlak gözüyle bakabiliriz." diyen Burhan Sait, Bulgaristan Türklerinin geleceğine dair umut taşımıştır (Sait, 1989).

Dördüncü yazı "Vardar" adıyla çıkmıştır. Bulgaristan'da 18 Aralık 1994'te yapılmak üzere erken seçim kararı alını. İçinde Bulgar ve Romanların da olduğu Türklerin kurduğu Hak ve Özgürlükler Hareketi lideri Ahmet Doğan, meclise 30 milletvekili sokacaklarını, Bulgar vatandaşlığını kaybetmeyen, Türkiye'ye göç etmiş Türklerden büyük destek göreceklerini belirtir. HÖH daha önce meclise 24 milletvekili sokabilmiştir. Kamuoyu yoklaması yapanlar ise, HÖH'ün 15 milletvekili çıkarabileceğini tahmin ederler. Türkler arasından çıkan iki yeni partinin Türk oylarını böleceği endişesi de bulunmaktadır (Vardar, 1994, s. 11).

Beşinci yazı, aslında Gagavuzya'ya yaptığı geziyi anlattığı ilk yazının içindeki bilgi şeklindedir. Burhan Sait, Sofya'da bile artık rahatça Türkçe konuşulabildiğini, Bulgaristan Türklerinin biraz rahatladığını belirtir (Sait, 1996, s. 12-16).

3.5. Irak Türkleri (Türkmenler) Üzerine Yazıları: Burhan Sait, bu konuda üç yazı yazmıştır. İlk yazı, Kerkük Türklerinden olup Kosova'da Tito Mitroviçası Jeoloji Fakültesi'nde okuyan Emir Kasapoğlu ile yapılan söyleşidir. Kasapoğlu, müzikle de uğraşan bir gençtir; bazı müzik gösterilerine katılmış, sesi de beğenilmiştir. Hatta "ilkbahar Şarkıcısı Festivali"nde birinci seçilmiştir. Kerkük'teyken de radyoda türküler söylediğini belirten Kasapoğlu, Priştine Radyosu Türk Sanat Müziği Orkestrası ile de şarkı ve türküler söyleyerek kendini kabul ettirir. Irak'ta o sırada 1.5 milyon Türk olduğunu, baskı yüzünden Arapça eğitim gördüğünü belirten 
Emir Kasapoğlu "Müzik yaşamın bölünmez bir parçasıdır. Müzik bir ulusun kültürüdür, özüdür bence. Bir ulus müziğiyle de kendisini diğer uluslara tanitabilir. Bu yönden hareket ederek ben de söylediğim Kerkük türküleriyle Irak'ta yaşayan Kerkük Türklerini tanıtma çabası içindeyim, varlıklarını tanıtma dileğindeyim." diyor (Sait, 1988).

İkinci yazı da Emir Kasapoğlu ile ilgilidir. Kasapoğlu okulunu bitirir, Almanya'da lisans üstü çalışma yapmayı düşünür. Önceki yazıda söylediklerini tekrarlar. Burhan Sait ise, Irak'ta 2 milyon Türk olduğunu belirtir. Kasapoğlu, Kerkük, Azerî ve Anadolu halk türkülerinin karışımı müzik icra etmektedir. Hatta Kerkük hoyratlarının ortasında uzun hava okumaktan hoşlandığını belirtir (Sait, 1990).

Üçüncü yazı "Vardar" adıyla çıkmış olup Irak Türkmenleri hakkındaki genel tanıtım ve onların güncel sorunlarıyla ilgilidir. Yazının bir kitaptan alınmış olabileceği izlenimi de söz konusudur. Türkmenlerin Irak'ta yaşadıkları bölgeler, tarihleri ve kültürleri, Osmanlı'dan ayrı kaldıktan sonra onlara her devirde yapılan baskılar, katliam ile kendilerinin mal varlıklarının korunması, Türkçe eğitim hakkının tanınması, nüfus oranına göre mecliste temsil edilmeleri, bölgelerinde Türkmenlerden de memur ve yönetici atamalarının yapılması gibi konular dile getirilmiştir (Vardar, 1996, s. 25-26).

3.6. Batı Trakya Türkleri Üzerine Yazıları: Burhan Sait'in bu konuda Vardar'da iki yazısı çıkmıştır. İlki 1991'de Türklerin oyuyla seçilen İskeçe Müftüsü Mehmet Emin Ağa'nın 10 ay hapis cezasına çarptırılması, makamından polis tarafından tartaklanarak alınması, yerine de Yunan hükümetinin atadığı kukla müftünün oturtulması üzerine yazılmıştır. Burhan Sait, "1923 yılında imzalanan Lozan Antlaşması'nın 37, 38, 39, 42 ve 44. maddeleriyle Batı Trakya'daki Türklerin her türlü dini, siyasi, ekonomik ve kültürel hak ve özgürlüklerinin Yunanistan tarafından tanınmış ve garanti altına alınmıştı" diyerek soruna hukuk açısından bakmıştır. Yunanlılar sistematik bir şekilde Türklerin haklarını gasp etmeye devam etmiş, Türk azınlığın kendisini "Türk" olarak görmesini yasaklamış, "Müslüman" terimini tercih ederek Türkiye'nin olaya karışmasına mâni olmaya çalışmıştır. Lozan Antlaşması imzalandığında 120.000 olarak kabul edilen Türk azınlık, aradan uzun zaman geçmesine rağmen hâlâ aynı sayıda gösterilmektedir. Halbuki sayının 300.000 civarında olduğu sanılmaktadır. Türklere araç, ehliyet alma, inşaat yapma izni vermemenin yollarına başvuran Yunanlılar, dağlardaki Türkleri "Pomak" diyerek asimile etmeye çalışmaktadır. Türklerin bir Türk'e toprak satması yasaktır. Bu durumda kalan Türkler, birbirinden resmî işlem yapmadan toprak almakta, toprak reformu yapmak bahanesine sığınan Yunan makamları, toprağı 
en son elinde bulunduran Türk'ten resmî belge istemekte, bu ibraz edilemeyince de toprağa el koymaktadır. Yunanistan, Lozan Antlaşmasıyla garanti altına alınan Müslüman Türk halkının müftülerini seçme hakkını 1990'da çıkardığı kanunla ortadan kaldırmış, isterse Hristiyan birini müftü atayabilme hükmünü getirmiştir. Yunanistan, Hristiyan bazı azınlıklara da aynı muameleyi yapmaktadır. Helsinki Komitesi bu konuda Yunanistan'ı uyardığı halde, Mehmet Emin Ağa sorununa ses çıkarmamıştır. Burhan Sait, Makedonya İslam Birliği ve Türk Demokratik Partisi'nin olaya sessiz kalmaması gerektiğini de belirtir (Vardar, 1995, s. 3-4).

İkinci yazı ise, bir esrarengiz kazada hayatını kaybeden Batı Trakya Türklerinin efsanevî lideri Dr. Sadık Ahmet'in ölümü üzerine yazılmış ve "Türk dünyası Balkan Türklerinin direniş sembolü, barış ve özgürlük savaşçısı Dr. Sadık Ahmet'i kaybetti. Esrarengiz bir kazada yaşamını yitiren Batı Trakya Türk liderlerinden Dr. Sadık Ahmet, haklı bir mücadelenin kahramanı olarak dünya Türklüğünün en yiğit evlatlarından biriydi. Gümülcine eski bağımsız milletvekili ve Dostluk-Eşitlik-Barış Partisi Başkanı Dr. Sadık Ahmet, Yunanistan'da yaşayan soydaşlarımızın insan hakları mücadelesini bayraklaştırmakla Türklerin hiçbir zaman zulüm karşısında kimseye boyun eğmeyeceğini kanıtlayan cesur bir siyaset adamıydı." diyen Burhan Sait, Dr. Sadık Ahmet'in mücadele yıllarını da anlatmıştır. 1980'li yıllarda hapse bile atılan Sadık Ahmet, 1989, 1990 seçimlerinde bağımsız milletvekili seçilebilmiştir. Yunanistan, ülke çapında yüzde $3^{\prime} \mid$ ük seçim barajını getirince, maalesef yeniden milletvekili seçilememiştir. Türkiye Cumhuriyeti Devlet Bakanı Yıldırım Aktuna'nın Batı Trakya'yı ziyareti sırasında Dr. Sadık Ahmet, Rodop Emniyet Müdürü tarafından ölümle tehdit edilmiş, mücadelesini bırakmadığı takdirde bir kazaya kurban gidebileceği imasında bulunulduğu iddia edilmiştir. 24 Temmuz 1995'teki kaza sırasında arabasında yanında olan ve sağ kalan eşi Işık Ahmet, Arabacis adında Yunanlı köylünün traktörüyle yol üzerinde beklemekte olduğunu, ona yaklaştıklarında traktörünü aniden önlerine sürdüğünü söylemiştir. Burhan Sait, yazısının sonunu "Balkan Türklerinin direniş simgesi Dr. Sadık Ahmet'in anısı önünde saygıyla eğilirken, Sadık Ahmetlerin ölmeyeceğini, onun izinden yürüyenlerin daha da artacağına güvenle inanıyoruz." ifadesiyle bitirmiştir (Vardar, 1995, s. 3-4).

3.7. Azerbaycan Üzerine Yazıları: Burhan Sait'in bu konuda iki yazısı vardır. İlk yazı "B.S" imzasıyla tan gazetesinde çıkmıştır. Sovyetler Birliği'nin dağılmasıyla bağımsız devlet olarak ortaya çıkan Ermenistan Cumhuriyeti ile Azerbaycan Cumhuriyeti arasında yüzyıl öncesinden kalan ihtilaflar Rusya, Avrupa Birliği ve ABD tarafından körüklenir. Stalin'in ince sinsi hesaplarıyla Azerbaycan içinde Karabağ, Ermenistan içinde de Nahçıvan özerk bölgeleri oluşturulur. Her iki 
özerk bölgede de Türkler çoğunluktaydı ama komünizm döneminde sistematik olarak Karabağ'a Ermeni nüfus yerleştirildi, çoğunluk Ermenilere geçti. Azerbaycan Cumhuriyeti'ndeki iktidar kavgalarını ve son dönem siyasîlerinden bazılarının Rus yanlısı tutumu yüzünden Karabağ Ermenileri, arada Azerbaycan toprağı olduğunu görmelerine rağmen Ermenistan'a bağlanmak mücadelesini başlatır. Sovyetler zamanında Azerbaycan Türklerinden pek subay yetiştirilmemesine rağmen, Ermenilere olabildiğince fazla hak tanınmıştır. Bölgedeki Rus birlikleri de onlara destek ve silah verir. Azerbaycan'da ise halkın büyük desteğiyle Ebülfez Elçibey Cumhurbaşkanı olur; Halk Cephesi iktidara gelir. Elçibey'e karşı darbe teşebbüsünde bulunanların Ruslara ve Ermenilerin oyununa karşı çıkmadıkları görülür. Rus birlikleriyle birlikte Karabağ'daki Ermeniler de, hem özerk bölgede hem de Azerbaycan topraklarında işgale başlar, katliam yapar. Hocalı katliamı bu sırada yaşanır. Burhan Sait, net bilgilerin olmadığı o günlerde Hocalı'da 1000 Azerbaycan Türkünün katledildiğini yazmıştır (Sait, 1992).

İkinci yazı "Vardar" imzasıyla çıkmıştır. Daha önce Fransa Cumhurbaşkanı Mitterand ile Ermenistan Devlet Başkanı Levon Ter Petrosyan bir anlaşma imzalıyorlar. Fransa, Karabağ'ın Ermeni toprağı olduğunu kabul ediyor, Fransa vatandaşı 70.000 Ermeni'yi Karabağ’a yerleştirme hesabı yapıyor; karşılığında ise Karabağ'daki zengin altın ve kırmızı cıva madenlerini işletme hakkını alıyor. Fransa, ayrıca yayınladığı Büyük Ermenistan haritasında, sınırları Malatya, Adana, Mersin ve Hatay'ın kuzey kısımlarını ve hatta Kuzey Azerbaycan ile Gürcistan'ı içine alacak şekilde göstermiştir. Fransa, AB fonlarından Erivan'a 100 milyon dolar kredi de sağlamıştır. Burhan Sait yeni gelişmeleri de

“Lübnan'daki Israil operasyonu sırasında tahliye edilen binlerce Ermeni, Suriye'nin başkenti Şam'a getirilerek buradan Ermenistan'a gönderiliyor. Karabağ'daki Ermeni nüfusunun arttırılması, Ermeni işgalinin güçlendirilmesi için Ermenistan yönetimi tarafından 1993 yılında da benzeri bir operasyon gerçekleştirilmişti. $O$ dönemde bu işlem bizzat Suriye içiş̧leri Bakanlığı tarafından yürütülmüş, fakat Türkiye'nin girişimleri ile bu durum engellenmişti. Ancak sevkiyat bu yıl yeniden başladı. Bu operasyonu Ermenistan, Suriye ve Fransa finanse ediyor." şeklinde vermiştir (Vardar, 1996, s. 25-26).

3.8. Gagavuzya ve Gagavuz Türkleriyle ilgili Yazıları: Burhan Sait'in Vardar'ın iki sayısında "Gezi I ve Gezi II" sütunu altında Gagavuzlar üzerine gezi izlenimlerini yansıtan iki yazısı bulunmaktadır. İlk yazı Gagavuzlar üzerine genel bilgiler, Moldovya ile ilişkiler üzerine yazılmıştır. Gagavuzların çoğunluğu, Moldova Cumhuriyeti'ndeki “Gagavuzya Otonom Bölgesi”nde yaşamaktadır. Burhan 
Sait, bir kısmının da Ukrayna, Romanya, Bulgaristan, Türkiye, Kazakistan, Kırım ve Arjantin'de yaşadığını belirtir. Gagavuzlar, Seyhun ve Ceyhun ırmakları bölgesinden göç etmiş ve zamanla Hıristiyanlığı kabul etmiş Oğuzlardır. Türkçelerini kaybetmedikleri için Türklüklerini korumuşlardır. Burhan Sait bundan dolayı "Tarihte Türkçe eğitim görmeyen bir kitlenin dilini, eski Türk örf ve adetlerini muhafaza etmesi ise ayrı bir mucize. Hıristiyanlığı benimseyen Avar ve Peçenek gibi Türk boylarının Slavlar arasında eriyip yok oldukları düşünüldüğünde Gagavuzların Türk kimliğiyle bugüne gelmeleri üstün bir milli bilincin ürünü olabilir ancak." diyor. Burhan Sait, Sofya, Bükreş hattından Moldova'nın başkenti Kişinev'e varır. Buralarda Türkiye mallarını ve şirketlerini görür. Gagavuzya Otonom Yönetimi Başkenti Komrat'ta Ayna Oteli'ndeki yaşlı Gagavuz Ana Petrovna ona Türkçe olarak "Çocuğum Türkiye'den bu otele çok misafir geliyor. Ama Makedonya'dan gelen ilk sizsiniz. Siz de memnun kalacaksınız." diyor. O sırada Komrat’ın nüfusu 35.000'dir. Gagavuzlar bağımsızlık sonrasında bölgeyi Moldov ve Romen görmek isteyenlerle mücadele etmiştir. Şehir meydanına koskocaman bir Türk Dünyası haritası yerleştirilmiş durumdadır. Burhan Sait, Halk Topluşu'nda (meclis) milletvekili ve Emniyet ile Hukuk Komisyonu Başkanı İvanoviç Çeban ile görüşür. Çeban, Moldova'da belli bir ağırığı olan Romen milliyetçilerinin Moldova'nın Romanya ile birleşmesi için çok uğraştıklarını, Gagavuzların buna direndiklerini, 1989'da "Gagavuzya Özerk Cumhuriyeti"ni ilan ettiklerini ama Moldova ve Rusya'nın bunu tanımadığını; Moldova Halk Cephesi'nin Gagavuzya'yı işgal etmek istediğini, Gagavuzların buna mâni olduklarını söylemiştir. 1993'te Moldova'yı ziyaret eden Türkiye Cumhurbaşkanı Süleyman Demirel, Gagavuzların Türkiye ile Moldova arasında bir dostluk köprüsü olacağını ifade etmiştir. Moldova'da seçimleri milliyetçi Halk Cephesi'nin kaybetmesi ve yeni meclisin “Gagavuzya Özerk Yönetimi"ni tanıması sorunu halletmiştir. Gagavuzya Halk Topluşu, içteki her kararı almaya yetkilidir. Resmî diller Gagavuzca, Rusça ve Romence'dir. Gagavuzya'daki seçimlerde 27 Gagavuz, 4 Moldovan, 2 Ukraynalı ve 2 Bulgar milletvekili seçilmiştir. Burhan Sait, "Gagavuz Türkleri'nde eğitim düzeyi çok yüksek. Her branştan uzman kadroları, bilim adamları olan Gagavuzlar arasında atom fiziği uzmanları da var.... 1990 yılında kurulan üniversite 1991 yılında resmi olarak çalışmaya başlıyor." demiştir. Komrat Devlet Üniversitesi Rektörü Prof. Dr. Stepan Varban, 1500 öğrencileri olduğunu ama şimdilik eğitim dilinin Rusça olduğunu belirtir. Üniversitede Türkiye'den de 20 civarında öğrenci okumaktadır. Halk Topluşu, yeni yıllarda Latin alfabesine geçmeyi ve Gagavuzca eğitim yapma kararı almıştır. Bölgede Latin harfleriyle çıkan Gagavuz Sesi gazetesi ve Sabah Yıldızı dergisi vardır. Yeni Ay adında özel bir televizyon kanalı yayına başlamıştır. Tarım ülkesi olan Gagavuzya'da sanayi çok zayıftır. Rusya'ya bağımlık çok fazladır. Türk iş adamları bölgede yatırımlara başlamışlardır. Bir işçi ayda ortalama 50 dolar maaş almaktadır. Bu ekonomik sıkıntı, suç artışına sebep olmaktadır (Sait, 1996, 
s. $12-16)$.

Burhan Sait, ikinci yazısında bölgenin Rus etkisi ve baskısından kurulamadığını, bazı yöneticilerin Kişinev'den çok Moskova'ya dönük politika izlediklerini, Halk Topluşu'nun milletvekilleri arasında da bunun görüldüğünü yazmıştır. Çeban, "Sovyetler Birliği döneminde hiç olmazsa kimse aç değildi. Herkesin bir işi vardı. Çalma, çırpma, yolsuzluk hiç denecek kadar azdı. Oysa şimdi tam aksine. Insanların çoğu kaçakçılık, karaborsa ve seyyar satıcılıkla geçimini sağlamaya çalışıyorlar. Binlerce işçinin çalıştığı Kolhozlar devre dışı bırakıldı. Insanlar kış aylarını nasıl atlatacak diye derin derin düşünüyor. Rusya'dan gelen gasın fiyatı eskisi gibi değil. Eskiden eğitim ve kültür sorunları yoktu. Insanlar bu yüzden işte eski Sovyetler Birliği'ne nostalji hissediyor." diyerek acı gerçeği itiraf ediyor. Çeban, karamsarlığını da gizlememiştir. Halk Topluşu Başkanı Petr Paşalı da "Eski Sovyetler Birliği cumhuriyetlerini Avrupa Birliği modelinde görmek istiyorum. Ortada fakir kalmasın." diyor. Halk Topluşu yayın organı "Gagavuzya'dan Haberler" gazetesi, Kiril harfleriyle Rusça olarak çıkmaya devam etmektedir ama yine de Gagavuzlar arasında dil ve millî kimliği yerleştirmeye çaba harcayanlar çoktur. "Gagavuz Sesi" gazetesi millî-milliyetçi çevrenin sözcüsüdür. Gazetenin düzenlediği bir panelde yazar Nikolay Baboğlu, "Biz özerkliği Rus dilini kullanmak için benimsemedik. Dili olmayan bir özerklik bize gerekmez. Biz Rus diline karşı değiliz, ama, Gagavuzca (Türkçe) başta olacaktır. O zaman biz de dilimizi unutmayacağız. Kendimizi milli sayacağız. Gagavuzlar gözünüzü açınız. Gagavuz olduğunuzu anlayınız. Vatanımızı, toprağımızı, dilimizi kurtarmalıyız." demiştir. Panelde Halk Topluşu yönetiminde bulunanların çoğunun maalesef özerkliğe karşı oldukları, Gagavuzca'yı savunanları milliyetçilik yapmakla suçladıkları da vurgulanmıştır. Panele Halk Topluşu yönetiminden kimsenin katılmayışı da dikkati çekmiştir. Yönetimle millî çevreler arasında sürtüşme, sadece dille ilgili de değildir. Millî çevreler, Gagavuzya'nın Moskova yerine Türk Dünyasına açılmasını istemektedir. Yönetim bu konuda suskundur. Burhan Sait bunun, "böl-yönet" politikasının sonucu olduğunu, 6 yıl kadar önceki özerklik, millîlik heyecanının gevşediğini; iki cephenin oluştuğunu belirtmiştir (Sait, 1996, s. 12-13).

3.9. Romanya Türkleri Üzerine Yazısı: Vardar imzasıyla yazılan yazıda Romanya'daki Müslüman Türklerden iki şairin şiir kitapları tanıtılıyor. Burhan Sait, başta "Kendilerini büyük Türk dünyasının bir parçası olarak gören Romanya'daki Müslüman Türk ve Tatar azınlık, 'Dilde, Fikirde, İşte Birlik" sloganıyla seslerini duyurma çabası içinde mücadele ediyor" diyor. Önce Romanya Türk Tatarları Müslüman Demokratik Birliği Başkan Yardımcısı Yaşar Memedemin'in “Kalem Oyunları” şiir kitabı, sonra Köstence Ovidius Üniversitesi Türkçe Bölüm Sorumlusu Emel 
Emin'in "Arzu-Şiirler" şiir kitabı kısaca tanıtılıyor. Emel Emin'in kitabının "Çocuk Şiirleri", Nasreddin Hoca Fıkraları" bölümlerinden oluştuğu, şairenin öğretici ve toplumcu şiirler yazdığı; "Anadolu'ya Selam" ve "Vatan” şiirlerinin güzel olduğu belirtilir (Vardar, 1997, s. 19).

3.10. Özbek Şairi Usman Azimov Üzerine Yazısı: Burhan Sait, 27. Struga Şiir Akşamları için Makedonya'ya gelen Özbek Usman Azimov ile bir sohbet gerçekleştiriyor. Taşkent Yazarlar Birliği Sekreteri olan Azimov, Özbekistan'ın SSCB’nin en gelişmiş ülkesi ve 18 milyon nüfusunun olduğunu söylüyor. Yalnız okullarda Özbekçe eğitimin yapıldığı bilgisi yanlıştır. SSCB'de her cumhuriyette Rusça eğitim esastı. Şairin Özbekçe sekiz şiir kitabı çıkmıştır. "Suret Parçaları", "Hal", "Akıbet", "Ders", "2 Nisan"ın en fazla okunan kitapları olduğu belirtilir. Önde gelen Özbek yazarlarının adlarını da veren Azimov, Türkiye'den en çok okunanların Nazım Hikmet, Sabahattin Ali, Orhan Veli, Fazıl Hüsnü Dağlarca ve Reşat Nuri Güntekin olduğunu söylüyor. Bu listenin sosyalist baskıdan oluştuğu bellidir. Struga'ya gelince Yugoslavya'da Türklerin yaşadığını öğrenen Asimov'un şaşkınlığı için Burhan Sait, "Çünkü Struga'ya gelmeden önce, Yugoslavya'da Türklerin de yaşadığını işitmemiş bile. Sonra nerde kaldı Yugoslavya Türk yazını" diyor. Özbekçeye çevrilen "Makedon Şiir Antolojisi"nde hiçbir Türk şairine yer verilmemiştir. Azimov, Özbekistan’a döndükten sonra, Yugoslavya'da Türklerin yaşadığını ve Türkçe konuştuklarını, her sorana bunu anlatacağını vaat ediyor. (Sait, 1988).

\section{11. İran Azerbaycan'ından olup Yugoslavya'da üniversite eğitimi alan} iki Türk öğrenciyle yapılan sohbet: Türkiyeli ses sanatçısı Selda Bağcan'ın Priştine'deki konseri sırasında, İranlı iki Azerbaycan Türkü gencin, ondan ısrarla "Ayrılık" türküsünü istemelerine şahit olan Burhan Sait, sonra onlarla röportaj da yapıyor. Mehi Behnam, İran ve Türkiye'de Dişçilik Fakültesi'ni kazanamayınca, 1987'de Yugoslavya'da Novi Sad'daki Dişçilik Fakültesi'ne yazılıyor. Mehreddin Haşimi de aynı durumda, 1986'da Banya Luka'daki Dişçilik Fakültesi'ne yazılıyor. Sonra her ikisi de Priştine'de daha rahat edeceklerini düşünerek yatay geçiş yapıyor. Priştine'de Türk ortamında daha rahat yaşamaktadırlar. Mehi "Novi Sad'da biz bir yabancıydık. Oysa Priştine'de bunu bize hissettirmiyorlar."; Mehreddin de "Öğrenim koşullarının biz yabancılar için daha elverişli olması nedeniyle Priştine'ye geldim. Priştine'de milletle daha rahat ilişki kuruyoruz. Burada Türk halkının da yaşaması bizim için bir önceliktir." diyor. Sadece ev kiralarının pahalı olmasından ve ulaşımdan yakınmaktadırlar. Mehi, Priştine'de bir Türk aile yanında kalmak isteğini de belirtir. Öğrenciler ayda 400'er mark harcamaktadırlar ki, bu 
İran'da kendi bölgelerinde dört ailenin aylık masrafıdır (Sait, 1991).

\subsection{Burhan Sait'in Alparslan Türkeş'in Ölümü Üzerine Yazısı ile Namık} Kemal Zeybek'le Yaptı̆̆ı Mülakat: Türk Dünyası üzerine önemli girişimleri olan Alparslan Türkeş'in 4 Nisan 1997'de ölümü üzerine Vardar'da çıkan haber-yazıyı Burhan Sait'in yazdığı sanılmaktadır. Yazının başında, "Başbuğ" kelimesinin Osmanlılar zamanında bile kullanıldığı, 26 Eylül 1932'de Türkiye Cumhuriyeti Millî Eğitim Bakanı Reşit Galip'in Türk Dil Kurultayı açılış konuşmasında Atatürk'e "Türkiye'nin şanlı Reisi, Türk irfan aleminin dahi Başbuğu Gazi Mustafa Kemal Hazretleri" sözleriyle hitap ettiği belirtilir. Tam bir milliyetçi olan Türkeş, şartlar oluştuğunda Türklerin dünyada lider olacağına inanmıştır. Yazıda dünyada Türk'ün yaşadığı her toprağı vatan bilen Türkeş'in, İngiliz baskısına dayanamayıp, babasını da razı ederek ailece Türkiye'ye göç ettiği; Ali Arslan olan adını "Alparslan Türkeş" olarak değiştirip Kuleli Askerî Lisesine girdiği, Kara Harp Okulu ve Harp Akademisi'ni bitirdiği, 1944 Irkçılık-Turancılık Davası'nda tutuklandığı, işkence gördüğü, sonra beraat ettiği, 27 Mayıs Darbesi'nin "Kudretli Albayı" olduğu, Millî Birlik Komitesi içindeki sürtüşme sonuncunda 13 Kasım 1960'ta sürgün olarak Türkiye Cumhuriyeti Delhi Büyükelçiliği emrine verildiği, dönüşte siyasete atıldığı, girdiği Cumhuriyetçi Köylü Millet Partisi'ne genel başkan seçildiği, bu partinin adını 1969 'da Milliyetçi Hareket Partisi olarak değiştirdiği anlatılır. Türkeş, komünizm tehlikesine karşı, "Ülkücülük ve Ülkücüler" kavramlarının yerleşmesini sağlar. Türkeş'in Ankara'da karlı ve soğuk bir havada yapılan cenaze merasimine çok kalabalık-1.5 veya 2 milyon kişi- milliyetçi-Ülkücü topluluk katılmıştır (Vardar, 1997, s. 8-10).

İkinci yazı Namık Kemal Zeybek'le yapılan mülakattır. Türkiye Cumhuriyeti Eski Kültür Bakanı Namık Kemal Zeybek, Çalıklı Hıdrellez Şenlikleri Festivali sırasında yapılan Türk Halk Kültürü Sempozyumu'na bildiri sunmak üzere Makedonya'ya gidiyor. Daha önce Kültür Bakanı iken bölgeyi ziyaret eden Zeybek, Kosova'da iç savaş sırasında zarar gören Priştine yakınındaki Sultan Birinci Murat Türbesi'nin onarımını sağlatmıştır. Burhan Sait, Zeybek'in Türk Dünyası'na hizmetlerinin bilindiğini ve son olarak da Kazakistan Cumhuriyeti ile Türkiye Cumhuriyeti'nin ortak kurduğu, Türkistan şehrinde merkezinin bulunduğu Uluslararası Ahmet Yesevi Türk-Kazak Üniversitesi Mütevelli Heyet Başkanlığı'nı yürüttüğünü, yakında günlük gazete çıkaracağını belirtir. Zeybek söyleşide, 1990 yılına kadar Bulgaristan, Yugoslavya, Yunanistan, Irak, Kıbrıs Türklüğünün konuşulduğunu, Sovyetler Birliği'nin dağılması sonucu 5 Muhtar Türk Cumhuriyeti'nin bağımsız devletler haline geldiğini, kendilerine Türkiye'yi örnek aldıklarını, Türkiye'nin sorumluluğunun arttığını söylemiştir. Türkiye'yi sıkıntıya sokan terörolay- 
ları, Rusya ve Batı tarafından Türkiye Cumhuriyeti'nin Orta Asya'da önünü kesmek için desteklenmektedir. Zeybek, Balkan ve Kıbrıs Türklüğünü Türkiye Türklüğünün uzantısı saymakta haklıdır. On yıl kadar önce bölgeyi Kültür Bakanı olarak ziyaretinde Türkler, ondan "Türk Kültür Merkezi" kurulmasında yardımcı olmasını istemiş ama bu ziyarete kadar bunun gerçekleşmediğini hatırlatan Burhan Sait'e Zeybek, bunun bürokrasinin bazı değerlerin önemini kavrayamamasından kaynaklandığı cevabını veriyor, yeni Kültür Bakanına bu talebi ileteceğini vaat ediyor. Zeybek, Türkiye'nin Balkanlardaki Türkler için her ülkede eşit yurttaşlık hakkı için destek verdiğini; Türkiye ve üyesi olduğu NATO'nun Kosova durumuna müdahil olarak bölge insanının taleplerinin gerçekleşmesine çalışığını; Türk Dünyasında kültür birliğinin sağlanması için uğraşıldığını, hayatını bu sorunun halledilmesine ve geniş iş birliği yapmasına adadığını da belirtir. Gelecekten de ümitlidir (Sait, 1999).

\section{Sonuç}

Tito zamanı ve onun 1980'de ölümünden 1990'a kadar, devlet garantisi altında olan haklarından dolayı sosyalist rejime bağlı kalan Burhan Sait, ayrı bağımsız devletlerin oluşmaya başlamasıyla milliyetçi-Türkçü çizgide yer almıştır. Bu fikir doğrultusunda hayatını hem Kosova ve Makedonya'daki Türklerin gasp edilen haklarını elde etme ve korumaya hem de başka devletlerde yaşayan Türklerle ilgilenmeye adamışır. Onun gazetecilik faaliyetinin en önemli kısmını bu doğrultuda yürüttüğü çalışmalar oluşturmaktadır. O bu kapsamda, öncelikle yüzyılların araya soktuğu kopukluk yüzünden, öncelikle Türk topluluklarının millî kimliği idrak etmelerini, başka bölgelerdeki Türklerle ilişkileri ve bilhassa ekonomik ilişkileri arttırmalarını tavsiye etmiştir. Ona göre ilişkiler, uzun süredir tek bağımsız devlet olan Türkiye Cumhuriyeti üzerinden yapılmalıdır. Bu konuda sıkıntı, SSCB'nin dağılmasını müteakip ayrı devletler olarak ortaya çıkan cumhuriyetlerinin ne yapacağıyla ilgilidir. Dünyanın her yerindeki Türkler gibi Burhan Sait de, Türkiye Cumhuriyeti'nin bölgesinde siyasî, ekonomik ve askerî yönden kuvvetli ve kudretli olmasını arzulamıştır. O, Türkiye Cumhuriyeti'ni içine almak istemeyen $A B^{\prime}$ ye karşı da Türk Birliği'nin (TB) kurulmasını hararetle teşvik etmiş, bununla ilgili girişimleri desteklemiştir. Yeni Türk Cumhuriyetlerinin Latin alfabesine geçmelerinin kaynaşmayı hızlandıracağına da inanmış bir aydın Türk'tü. Çok genç yaşta hayatını kaybeden Burhan Sait, bütün ömrünü hem Kosova ve Makedonya hem de dünyanın değişik yerlerinde bazıları devletleşmiş, bazıları bölge devletlerinin egemenliğinde yaşayan Türklerin dertlerini dile getirmeye, bunlara çözüm göstermeye adamıştır. 


\section{Kaynakça}

Burhan Sait, buraya alınan yazılarını Burhan Sait, B. Sait, B.S., Vardar adlarıyla yazmıştır.

Sağlam, F. Mail, 07.06.2020.

Sait, B. (1988, Kasım). "Struga Şiir Akşamları'nda Özbekistanlı Şair Usman Azimov'un Anlattıkları: "Yugoslavya'da Türklerin de Yaşadığını Bilmiyordum". Tan.

Sait, B. (1988, Nisan). "Türkü Okumayı Çok Seven Türk Asıllı Iraklı Tito Mitroviçası'nda Jeoloji Fakültesi Öğrencisi Emir Kasapoğlu ile Başbaşa: Türkülerimde Kerkük ve Türkleri Yaşar". Tan.

Sait, B. (1989, Aralık). “Bulgaristan'daki Gelişmeler Ümit Verici. Mitinglerde Diyalog istemleri" Tan.

Sait, B. (1989, Kasım). "Sofya'da Sonbahar Yağmurları Neşeli Yağıyor. Bulgaristan'a da Geldi Bahar". Tan.

Sait, B. (1989, Temmuz). "Belgrad TV'si 2. Kanalında Sunulan "Bulgar Türklerinin Göçü" Yayını Geniş Yankı Yarattı. Yugoslavya Kamuoyu Bulgar Türklerinin Gerçek Durumunu Öğrendi". Tan.

Sait, B. (1990, Ağustos). "Irak'ta İki Milyon Türk". Tan, s.7.

Sait, B. (1990, Ağustos). "Türklerin Sayısı Ikiyüz Milyon". Tan.

Sait, B. (1990, Eylül). "Balkan Türkleri ve Demokrasi”. Tan.

Sait, B. (1990, Haziran). "Osmanlılardan Önce Bile Balkanlarda Türkler Yaşadı". Tan, s.5.

Sait, B. (1991, Şubat). "Türk Ailesinde Oturmak İstiyoruz". Tan.

Sait, B. (1992, Mart). "Ermeni-Azeri Anlaşmazlığının Getirdikleri: Soykırıma Varan Gerginlik". Tan.

Sait, B. (1992, Şubat). "Adriyatik'ten Çin Seddine". Tan, s.

Sait, B. (1993, Ocak). "Cuma'dan Cuma'ya Makedonya: Türk Birliğinin Sağlanmasını Engelleyen Gelişmeler". Tan.

Sait, B. (1996, Ağustos). “Gezi Il: Gagauzya'da Rus Etkisi ve Milli Mücadele". Vardar, s. 12-13. 
Sait, B. (1996, Temmuz). “Gezi I: Türk Diyarı Gagauzya”. Vardar, s. 12-16.

Sait, B. (1997, Kasım-Aralık). “AB Yoksa TB Vardır”. Vardar, s. 3-5.

Sait, B. (1999, Mayıs). "Türkiye Cumhuriyeti Eski Kültür Bakanı Namık Kemal Zeybek "Vardar"a Konuştu: "Balkan Türklüğü Türkiye Türklüğünün Uzantısıdır". Vardar.

Sait, B. (2000, Ekim). “29 Ekim'in Türk Dünyası İçin Önemi”. Vardar.

Vardar. (1994, Ağustos). "Türk Dünyasından Kısa Kısa”. Vardar, s. 25-26.

Vardar. (1994, Aralık). "Türk Dünyasından Kısa Kısa”. Vardar, s. 25-26.

Vardar. (1994, Ekim). "Türk Dünyasının Bayram Ayı". Vardar, s. 3.

Vardar. (1994, Eylül). "Türk Dünyasından Kısa Kısa". Vardar, s. 26.

Vardar. (1994, Haziran). "Türk Dünyasından Kısa Kısa”. Vardar, s. 26.

Vardar. (1994, Kasım). “Bulgaristan'da erken seçim heyecanı ve Türk partilerinin beklentileri... HÖH Başkanı Ahmet Doğan: "Otuzdan Fazla Milletvekili IIle Temsil Edileceğiz". Vardar, s. 11.

Vardar. (1994, Kasım). "Türk Dünyasından Kısa Kısa". Vardar, s. 25-26.

Vardar. (1995, Ağustos- Eylül). "Türk Dünyasında Ortak Alfabeye Doğru". Vardar, s. 25.

Vardar. (1995, Kasım-1996, Ağustos). "Türk Dünyasından Kısa Kısa". Vardar, s. 12-13.

Vardar. (1995, Nisan). "Türk Dünyasından Kısa Kısa”. Vardar, s. 26-27.

Vardar. (1995, Ocak). “Batı Trakya Türkü'nün Acısı Dinmiyor... Mehmet Emin Ağa". Vardar, s. 3-4.

Vardar. (1995, Ocak). "Türk Dünyasından Kısa Kısa”. Vardar, s. 27.

Vardar. (1995, Şubat-Mart). "Türk Dünyasından Kısa Kısa”, Vardar, s. 35.

Vardar. (1995, Temmuz). "Sadık Ahmet'ler Ölmez... Türk Dünyası Yiğit Bir Evladını Daha Kaybetti". Vardar, s. 3-4.

Vardar. (1996, Aralık). "Fransa Karabağ’a Ermeni Sevk Ediyor". Vardar, s. $25-26$. 
Vardar. (1996, Mart). "Türk Dünyasından Kısa Kısa”, Vardar, s. 25-26.

Vardar. (1996, Ocak). "Türk Dünyasından... Irak Türkmenleri”. Vardar, s. 25-26.

Vardar. (1997, Kasım-Aralık). “Romanya'dan Gelen Kardeş Selamı. Kalem Oyunları, Arzu". Vardar, s. 19.

Vardar. (1997, Mart-Nisan). "Son Başbuğ Alparslan Türkeş’i Kaybettik. Türkeş Türklük Dünyasının Bilge Lideriydi”. Vardar, s. 8-10. 